\title{
Design and Construction of a PBL Based Evaluation Index System for Classroom Music Education
}

\author{
https://doi.org/10.3991/ijet.v16i17.25649 \\ Mengsi Huang, Yingxue Zhang $(\bowtie)$ \\ Hubei Engineering University, Xiaogan, China \\ lzkity123@163.com
}

\begin{abstract}
The quality of classroom education is essential to the construction and development of departments and colleges, and a mirror of the teaching level and quality of teachers. Project-based learning (PBL) tries to create problem scenarios for learners, and encourage them to think deeper and communicate more. Inspired by PBL, this paper analyzes the existing evaluation index systems (EISs) for classroom music education in colleges, and summarizes the application of PBL in music teaching. Besides, a novel EIS is designed and constructed for classroom music education. The results show that: PBL stresses the changes of learners through the learning, and enables teachers to combine pre-, in-, and postclass methods to comprehensively evaluate the music literacy of students; PBL exerts a positive effect on students' learning. The results lay a theoretical basis for reforming the EIS of classroom music education.
\end{abstract}

Keywords-classroom education quality, project-based learning (PBL), evaluation index system (EIS), music literacy

\section{Introduction}

The responsibility of higher education is to cultivate senior talents, the classroom teaching is an important means for training high-quality college students, and the effect of classroom teaching directly determines the quality of college graduates $[1,2]$. The evaluation of the effect of classroom teaching should be guaranteed by a set of complete evaluation index system; the evaluation should go through the entire process from the organization of the class to the processing and feedback after the teaching results have been obtained, and a set of reasonable, scientific, and effective evaluation indexes should be formulated [3, 4]. The evaluation of classroom teaching is of very practical and realistic meanings, including stimulating teachers' enthusiasm for the teaching works, enforcing classroom teaching quality control of colleges and universities, and upgrading the classroom teaching quality of higher educational schools $[5,6]$.

The concept of PBL was first created by the McMaster University of Canada, the learning process in PBL simulates the process of problem solving. The knowledge and skills to be learnt are organized around the problem, and the learning is initiated by the students $[7,8]$. Scholars have evaluated the effectiveness of PBL by surveying the stu- 
dents, and the research results reveal that most students strongly agree that PBL is indeed helpful for cultivating their interest in learning, with the aid of PBL, they could have a better understanding of the knowledge and they will learn autonomously [9, 10]. The function of PBL is highly consistent with the curriculum reform goals in China, PBL has an intrinsic motivation to strengthen knowledge exploration, and it can enhance students' ability in dialectical thinking and problem solving [11, 12]. Compared with traditional classroom teaching methods, PBL advocates creating problem scenarios for learners and encouraging them to think and communicate. At the same time, online platforms can also provide learners with high-quality courses and communication venues, which is very useful for learners to interact and discuss [13, 14].

Regarding education-related evaluation, field scholars have pointed out different emphases, some argue that such evaluation should aim at rewards and punishments to highlight the management and diagnosis functions of the evaluation [15, 16], while some advocate taking development as the primary goal and the growth of teachers' overall competence as the center, and the teachers' teaching skills and levels should be improved by implementing evaluation on the classroom teaching quality of teachers $[17,18]$. Inspired by PBL, this paper analyzes the existing EISs for classroom music education in colleges, summarizes the application of PBL in music teaching, and proposes a novel EIS for classroom music education. This study hopes to offer a useful theoretical foundation for the reform of classroom music education in China.

\section{EIS for classroom music education in colleges}

\subsection{Status quo}

According to the statements of field scholars, the evaluation of the quality of classroom education is to judge the effect of teaching based on certain standards, these standards generally contain elements of the teaching activities, and the change and development of these elements would affect the judgement results [19]. The evaluation of classroom education should contain the setting of classroom teaching goals, the selection of teaching content, the design of teaching activities, the use of teaching methods, and the development of teaching skills, etc. [20]. The exam scores of students shouldn't be taken as the only criterion for judging the quality of classroom education [21, 22]. The basis for the evaluation of classroom music education in colleges includes the requirement of social development, the requirement of higher education development, the theories of pedagogy, the teaching goals of undergraduate education, the syllabus, and the teaching principles and features of music courses [23, 24]. The goals of classroom education are the core of teaching activities, and all teaching activities should be carried out centered on these goals $[25,26]$. In college music class, the learning of music is actually participated by both the teachers and the students, by experiencing and enjoying music works, teachers cultivate students' sentiments, increase their interest in music, and encourage them to pursue the beauty of music art [27, 28]. 
Figure 1 summarizes deficiencies in current classroom music education evaluation, including: current evaluation ignores the guidance and diagnosis functions of the evaluation; the EISs are incomplete and lack of scientific evidence; the evaluation criteria lack flexible and developmental indexes, and they are too stylized; the evaluation process relies too much on manual operation, which is toilsome and error-prone; the evaluation is not systematic and the evaluation results are not comprehensive; the teaching quality information feedback mechanism is lagging, which has results in delayed feedback and simplex information. In terms of music education in colleges, teachers are the primary factor in classroom education evaluation, for the evaluation of teachers, there should be clear evaluation objectives and scientific evaluation views; schools and teachers should objectively reflect on the teaching evaluation results of classroom music education, and the evaluation views would eventually become a key factor affecting the evaluation results of the quality of classroom music education in colleges [29].

\begin{tabular}{|l|c|}
\hline $\begin{array}{c}\text { Ignore the "guide" and "diagnosis" functions of } \\
\text { classroom education evaluation }\end{array}$ \\
\hline $\begin{array}{c}\text { Shortcomings in } \\
\text { the evaluation of } \\
\text { music classroom } \\
\text { education }\end{array}$ & $\begin{array}{c}\text { Evaluation criteria lack of flexibility and } \\
\text { development indicators, too stylized } \\
\text { scientific demonstration }\end{array}$ \\
\hline $\begin{array}{c}\text { The evaluation process mostly relies on the } \\
\text { original manual operation, which is complicated } \\
\text { and error-prone }\end{array}$ \\
\hline $\begin{array}{c}\text { The evaluation is not carried out systematically } \\
\text { and the evaluation results are not comprehensive }\end{array}$ \\
\begin{tabular}{|c|} 
The feedback system of teaching quality \\
information lags behind, and the feedback is not \\
timely and lacks timeliness
\end{tabular} \\
\hline $\begin{array}{c}\text { Lack of incentive measures, unable to mobilize } \\
\text { the enthusiasm of teachers to improve the quality } \\
\text { of teaching }\end{array}$ \\
\hline
\end{tabular}

Fig. 1. Deficiencies in current classroom music education evaluation 


\subsection{Countermeasures}

The evaluation of classroom music education in colleges should conform to the law of music teaching, and the trend of music education reform [30, 31]. Figure 2 proposes three countermeasures to improve the evaluation of classroom music education in colleges. The first is establishing a modern evaluation view, we should take the evaluation given by students seriously, so that teachers could get the real information and improve the teaching quality $[32,33]$. The second is establishing a complete and scientific college music education evaluation system, and the teacher's self-evaluation, the student evaluation, and the expert evaluation should all be included in the structure of this system $[34,35]$. The third is establishing a reasonable and scientific EIS with reasonable index weight values, comprehensive indexes, operable evaluation standards, sound online teaching evaluation platform, and complete feedback and tracking mechanism.

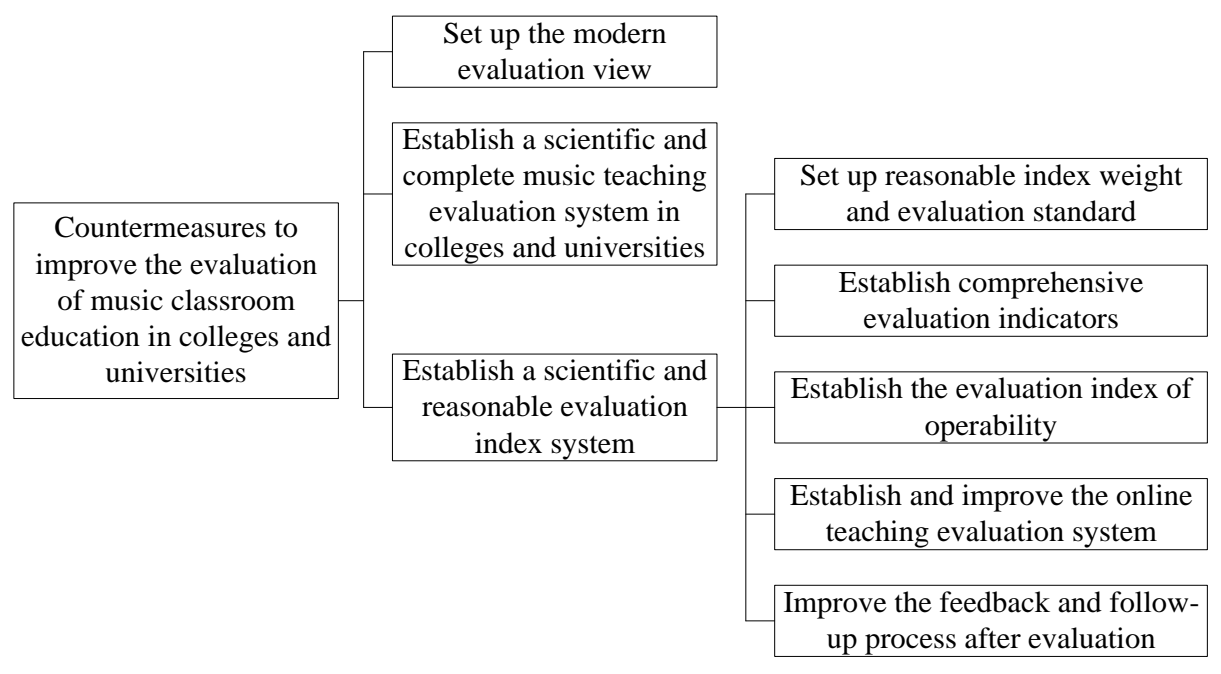

Fig. 2. Countermeasures to improve the evaluation of classroom music education in colleges

\section{Application of PBL in classroom music education}

\subsection{Teaching flow design based on PBL}

Both in the teaching of practice and the teaching of theory, PBL has certain advantages in music-related courses. Figure 3 shows the teaching design flow based on PBL. The flow chart clearly gives PBL processes, including the preparation before class, raise questions, analyze questions, solve questions, results display, and feedback evaluation; corresponding to these processes, the teachers need to make clear of the teaching goals, set the teaching problems, list difficult and key points, instruct study groups to answer the questions, assist students to finish the teaching tasks, observe students' performance during presentation and give guidance, organize students to evaluate and analyze each other and give feedback. As for students, they need to analyze the 
problems, take exercises repeatedly after class. In the entire problem-solving process, PBL increases students' initiative and enthusiasm to participate in learning, and enhances their ability in discovering, analyzing, and solving the problems.

In order to figure out the effect of PBL on music education, our research team selected a few music major students from Shandong Normal University as the subjects. In our experiment, one class was taken as the test group, one class was taken as the control group, and the teaching experiment lasted for 12 class hours. Before the experiment, a questionnaire survey was conducted to research the feasibility of PBL, and 61 respondents from the two classes had participated in the survey. A total of 60 valid questionnaire were returned, and the results show that most of the respondents think that PBL has given them more liberty to adjust the time, space, and rhythm of learning by themselves.

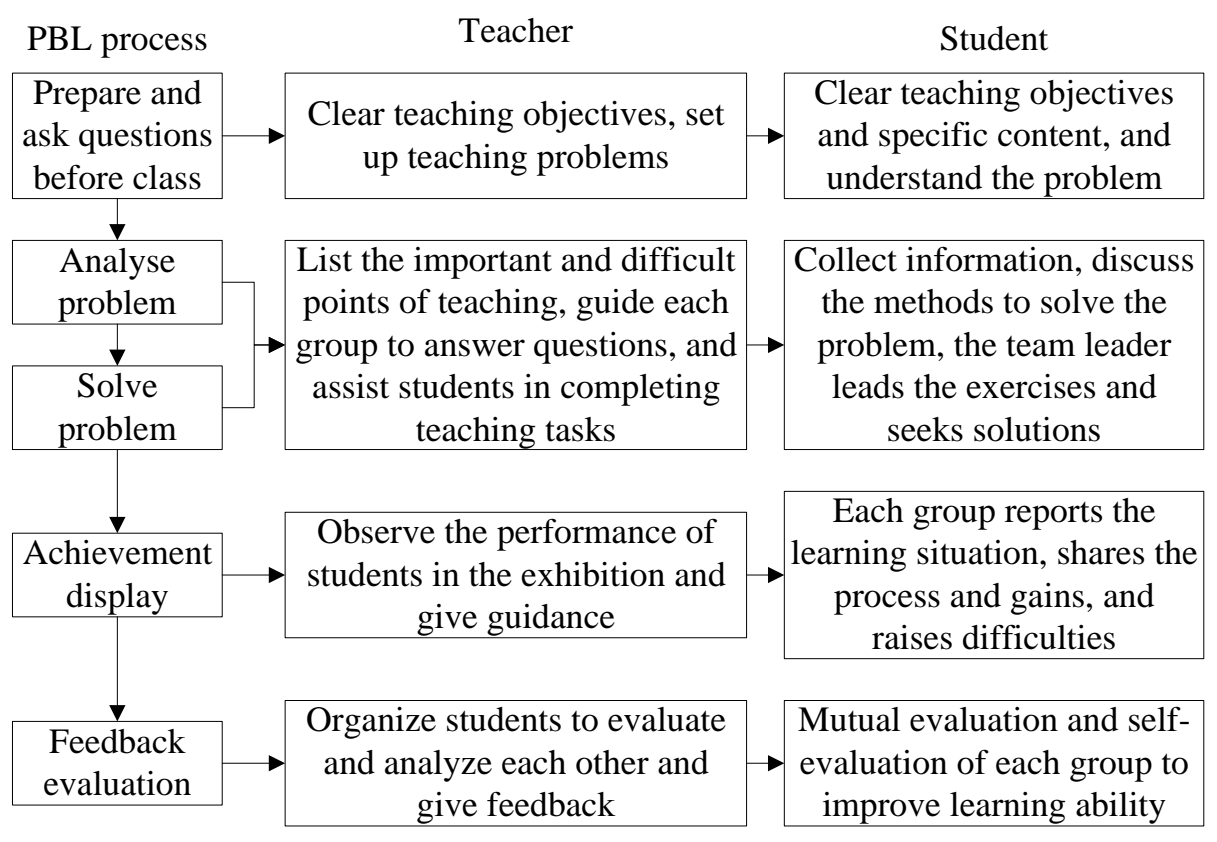

Fig. 3. Teaching design flow based on PBL

\subsection{Application effect of PBL}

The implementation process of PBL contains three stages: pre-class review based on PBL, classroom teaching based on PBL, and after-class review based on PBL. Music is an art subject, its teaching stages include: scenario creation, new knowledge introduction, consolidating training, and class summary, etc. PBL emphasizes on the students' changes during the entire learning process, and teachers could combine the various pre-class, in-class, and after-class evaluation methods together to give a comprehensive evaluation on the music literacy of students. Figure 4 is a comparison of the music course scores of students before and after applying PBL. Before the experiment, 
the two classes were tested for their music course scores, and the control group and test group respectively scored an average of 84.91 points and 85.77 points. In the experiment, the control group still adopted the previous teaching method, while the test group was taught by the PBL method. After 12 class hours, the average scores of the two groups were 83.23 and 95.41, respectively. Obviously, the score of the test group was higher than that of the control group, there're significant differences between the two groups, and it indicates that the PBL had a positive effect on the learning of students.

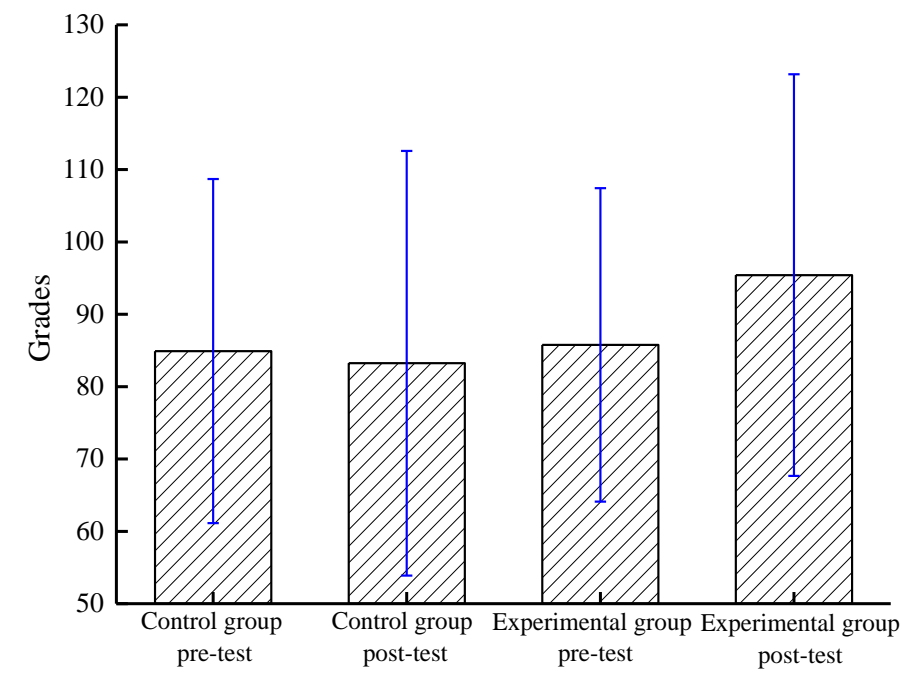

Fig. 4. Comparison of music course scores of students before and after applying PBL

\section{Construction and design of the new EIS for classroom music education}

\subsection{About the new EIS}

Classroom teaching is an important means of teaching activities, and the evaluation of classroom teaching quality is the most important part of the teaching works in colleges and universities. Figure 5 shows the principles of classroom teaching quality evaluation. The evaluation on the classroom teaching quality should follow the scientific, credible, feasible, comparable, and complete principles. Figure 6 is a diagram of the classroom teaching quality evaluation system. The entire system consists of two parts: the decision-making and command sub-system and the information collection and evaluation sub-system. The decision-making and command sub-system is organized by the schools, departments, and teaching research offices in the college; the information collection and evaluation sub-system contains the student evaluation, the expert evaluation, and the management evaluation, etc. The evaluation indexes that constituted the system should be clearly configured at each level, and all indexes should have clear connotations, definitions, and calculation methods. Figure 7 lists indexes in the newly 
designed EIS. The first-level indexes include teaching objectives, teaching content, teaching implementation, teaching benefits, teaching attitude, and teaching characteristics, etc. The second-level indexes under the first-level index teaching objectives are adaptability and forward-looking; the second-level indexes under the first-level index teaching content are fundamentality, academic nature, and ideology; the second-level indexes under the first-level index teaching implementation are heuristics, artistry, and technicality; the second-level indexes under the first-level index teaching benefits are fullness and effectiveness; the second-level indexes under the first-level index teaching attitude are sense of responsibility and rigorousness; the second-level indexes under the first-level index teaching characteristics are individuality and creativeness. In the evaluation process, each index provides information separately, there's no overlap between the indexes, and the selected evaluation indexes should give a comprehensive consideration to the elements contained in the classroom teaching of teachers.

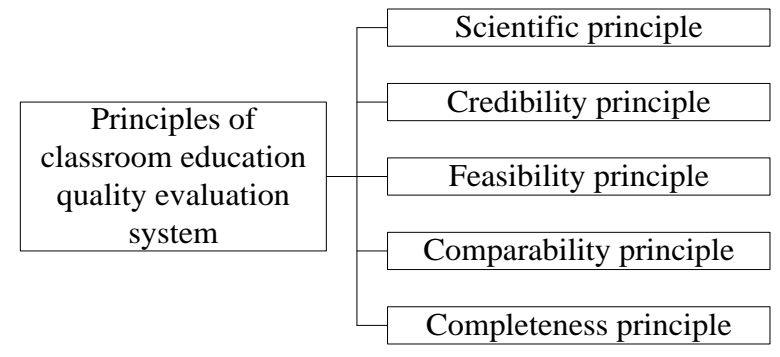

Fig. 5. Principles of classroom teaching quality evaluation

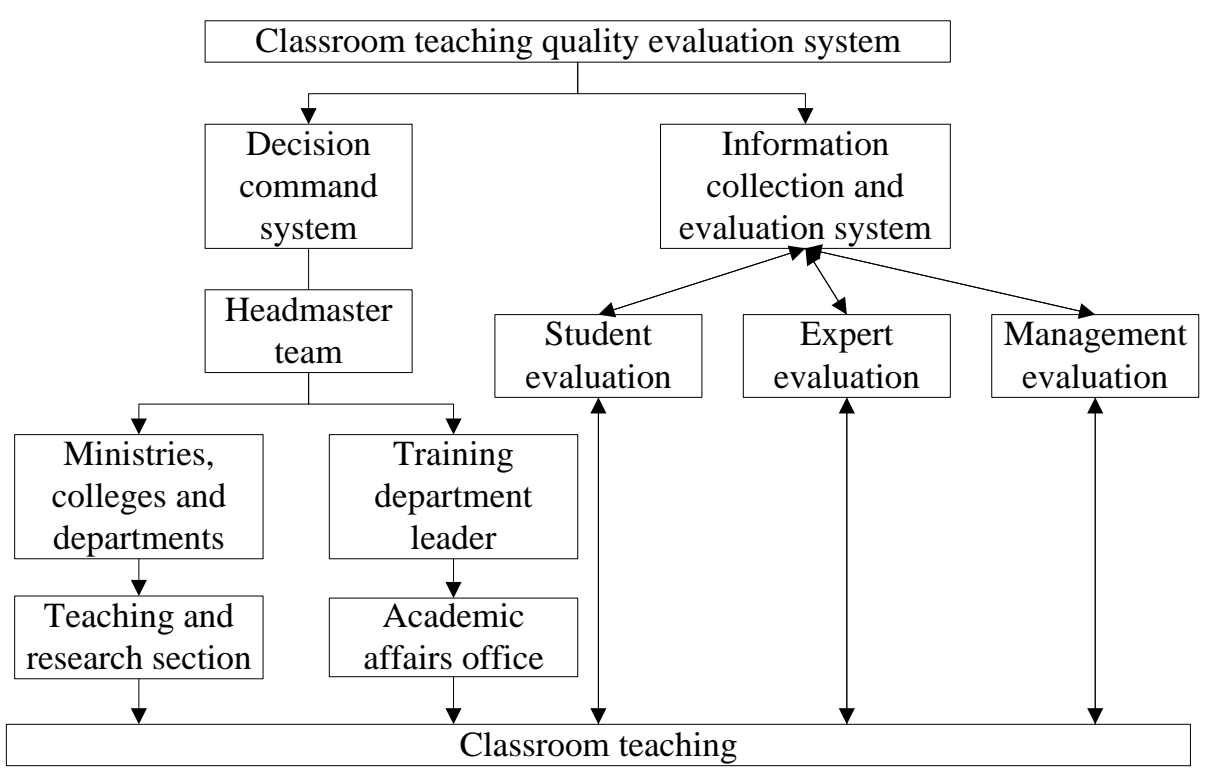

Fig. 6. The classroom teaching quality evaluation system 


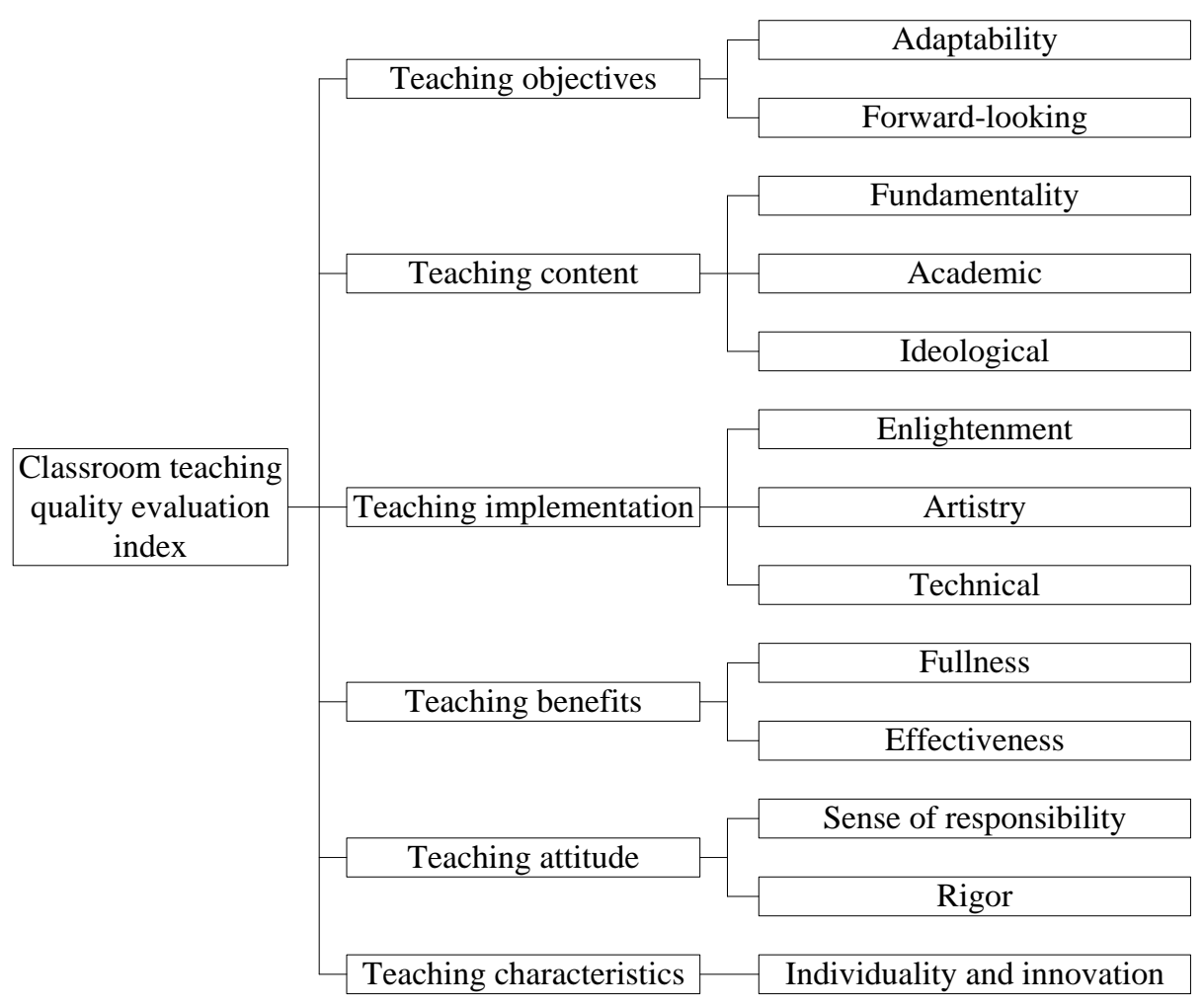

Fig. 7. Indexes in the newly designed EIS

\subsection{A practice of the proposed evaluation system}

Current colleges are forging efficient teaching quality management, evaluation, and monitoring systems for subjects and courses. Figure 8 lists features and functions of the proposed database-based teaching quality evaluation system. The database system has powerful information management function, it can realize data sharing, allow teachers to view the scores and suggestions given by students for each evaluation index. With the aid of this system, the effectiveness and credibility of the evaluation could be enhanced, the effectiveness of the input data could be guaranteed; since the operations are performed via the Internet, a lot of manpower and material resources could be saved; moreover, the system could make sure that the evaluation is dynamic and in real time; the system has functions such as automatic analysis, statistics, and sorting, and setting different access permissions for different roles.

Survey results show that more than $95 \%$ of teachers and experts believe that the proposed EIS is reasonable. The evaluation scores of 9 music teachers from Shandong Normal University were counted using the student evaluation and expert evaluation methods. Figure 9 shows the evaluation results of music education experts. In the expert evaluation scores, the excellent rate gradually increased over the semesters, overall, the proportion of excellent rate and good rate of each semester were above $90 \%$. Figure 10 
shows the evaluation results of music students. In the student evaluation scores, the excellent rate exceeded $40 \%$, and the proportion of excellent rate and good rate exceeded $95 \%$, overall, students approved of the teaching level of music teachers.

\begin{tabular}{|c|c|}
\hline $\begin{array}{c}\text { Database has strong management } \\
\text { capabilities for data }\end{array}$ \\
\hline $\begin{array}{c}\text { Tealize the data sharing of classroom } \\
\text { education evaluation } \\
\text { functions of teaching quality } \\
\text { evaluation system based on } \\
\text { information database }\end{array}$ \\
\hline \multirow{1}{*}{$\begin{array}{c}\text { Ensure the validity and credibility of the } \\
\text { evaluation }\end{array}$} \\
\hline \begin{tabular}{c} 
Ensure the validity of the entered data \\
\hline Operate via the Internet, saving manpower \\
and material resources
\end{tabular} \\
\hline Dynamic evaluation, real-time feedback \\
\hline $\begin{array}{c}\text { Data real-time, dynamic, automatic } \\
\text { analysis, statistics and sorting functions }\end{array}$ \\
\hline Set different access permissions \\
\hline
\end{tabular}

Fig. 8. Features and functions of the proposed database-based teaching quality evaluation system

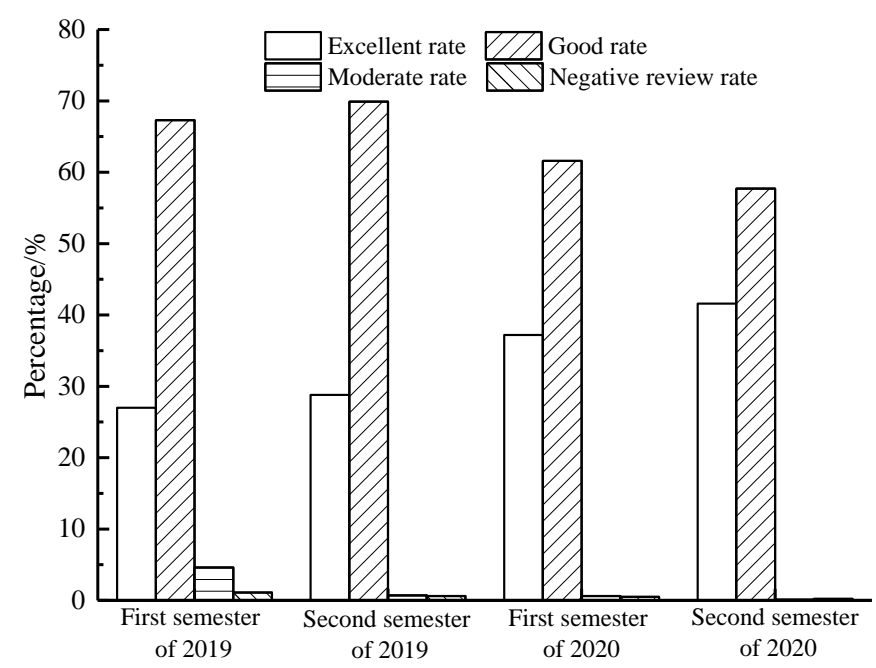

Fig. 9. Evaluation results of music education experts 


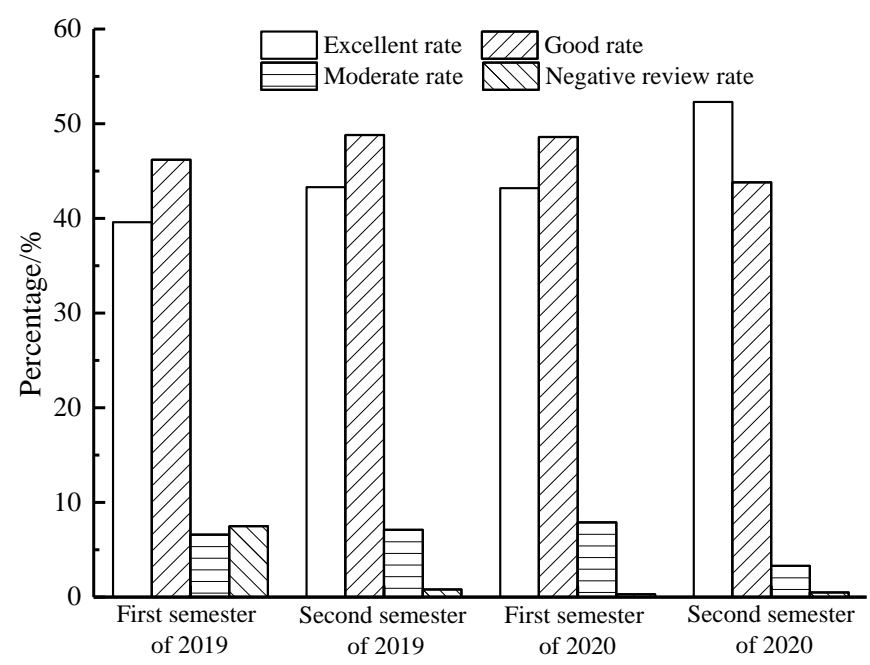

Fig. 10.Evaluation results of music students

\section{Conclusions}

Based on PBL, this paper analyzed the status quo of existing EISs for classroom music education in colleges, summarized the application of PBL in music teaching, and proposed a new EIS. The specific conclusions are as follows:

1. PBL has certain advantages in music-related courses. The teaching design flow based on PBL clearly gives the PBL processes, including the preparation before class, raise questions, analyze questions, solve questions, results display, and feedback evaluation.

2. The implementation process of PBL contains three stages: pre-class review based on PBL, classroom teaching based on PBL, and after-class review based on PBL. PBL emphasizes on the students' changes during the entire learning process, and teachers could combine the various pre-class, in-class, and after-class evaluation methods together to give a comprehensive evaluation on the music literacy of students.

3 . The evaluation on the classroom teaching quality should follow the scientific, credible, feasible, comparable, and complete principles. The entire evaluation system consists of two parts: the decision-making and command sub-system and the information collection and evaluation sub-system. In the evaluation scores given by experts and students, the proportion of excellent rate and good rate respectively exceeded $90 \%$ and $95 \%$. 


\section{$6 \quad$ References}

[1] Lengyel, P.S. (2020). Can the Game-Based Learning Come? Virtual Classroom in Higher Education of 21st Century, International Journal of Emerging Technologies in Learning, 15(2), 112-126. https://doi.org/10.3991/ijet.v15i02.11521

[2] Yang, C.B., Huan, S.L., Yang, Y. (2020). Application of Big Data Technology in Blended Teaching of College Students: A Case Study on Rain Classroom, International Journal of Emerging Technologies in Learning, 15(11), 4-16. https://doi.org/10.3991/ijet.v15i11. $\underline{14519}$

[3] Jacques, S., Lequeu, T. (2020). The Attractiveness of Reversing Teaching Forms - Feedback on an Electrical Engineering Course, International Journal of Engineering Pedagogy, 10(3), 21-34. https://doi.org/10.3991/ijep.v10i3.12361

[4] Stelios, S., Christodoulou, A. (2020). Teaching Professional Integrity: An Empirical Study on Engineering Students, International Journal of Engineering Pedagogy, 10(3), 98-105. https://doi.org/10.3991/ijep.v10i3.12013

[5] Block, E., Breaud, M., Cavalier, S., Guidry, L., Perry, M. (2019). Pre-kindergarten teachers' understanding and perceptions of the classroom assessment scoring system (class). Creative Education, 10(9): 1988-1998. https://doi.org/10.4236/ce.2019.109145

[6] Wu, Y., Wu, T., Li, Y. (2019). Impact of using classroom response systems on students' entrepreneurship learning experience. Computers in Human Behavior, 92: 634-645. https:// doi.org/10.1016/j.chb.2017.08.013

[7] Chen, W., Hao, Y.F., Jin, N.Q.J. (2019). Product collaborative innovation of project-based supply chain under the influence of knowledge input.Journal Européen des Systèmes Automatisés, 52(3), 243-251. https://doi.org/10.18280/jesa.520304

[8] Liu, J.L., Li, K. (2019). An information system of clinical pathway management based on the integration between knowledge management and learning organization. Ingénierie des Systèmes d'Information, 24(5), 473-480. https://doi.org/10.18280/isi.240503

[9] Daly, D., Rasmussen, A.V., Dalsgaard, A. (2019). Learning about midwifery in another country from a distance: evaluation of a virtual classroom learning session. Nurse Education Today, 75: 47-52. https://doi.org/10.1016/j.nedt.2019.01.007

[10] Scheerens, J., Blmeke, S. (2016). Integrating teacher education effectiveness research into educational effectiveness models. Educational Research Review, 18: 70-87. https://doi.org/ $\underline{10.1016 / j . e d u r e v .2016 .03 .002}$

[11] Junpeng, P. (2012). The development of classroom assessment system in mathematics for basic education of thailand. Procedia - Social and Behavioral Sciences, 69(1): 1965-1972. https://doi.org/10.1016/j.sbspro.2012.12.152

[12] Li, X.D., Xie, F., Li, X.Q., L,i G.W., Chen X., Lv, J., Peng, C.Y. (2020). Development, application, and evaluation of a problem-based learning method in clinical laboratory education - sciencedirect. Clinica Chimica Acta, 510: 681-684. https://doi.org/10.1016/j.cca. $\underline{2020.08 .037}$

[13] Mca, B., Sab, C. (2020). Evaluation of an intervention to support the development of clinical problem solving skills during a hospital-based experiential learning program for south african pharmacy students. Currents in Pharmacy Teaching and Learning, 12(5): 590-601. https://doi.org/10.1016/j.cptl.2020.01.016, https://doi.org/10.1016/j.cptl.2020.05.001

[14] El-Magboub, A., Haworth, I.S., Sutch, B.T., Romero, R.M. (2016). Evaluation of in-class and online discussion meetings in a biopharmaceutics problem-based learning class. Currents in Pharmacy Teaching \& Learning, 8(6): 811-820. https://doi.org/10.1016/j.cptl. $\underline{2016.08 .021}$ 
Paper - Design and Construction of a PBL Based Evaluation Index System for Classroom Music...

[15] Sun, C., Qi, X. (2017). Evaluation of problem and simulator-based learning on lumbar puncture of adult neurology residency training. World Neurosurgery, 109: e807-e811. https://doi.org/10.1016/j.wneu.2017.10.093

[16] Mishra, K., Ross, J., Goldfarb, D.A., Goldman, H.B., Campbell, S.C. (2015). Evaluation of an electronic platform for problem based learning for subspecialty fellows. Urology Practice, 2(3): 133-137. https://doi.org/10.1016/j.urpr.2014.10.005

[17] Al-Kloub, M.I., Salameh, T.N., Froelicher, E.S. (2013). Nursing students evaluation of problem based learning and the impact of culture on the learning process and outcomes: A pilot project. Nurse Education in Practice, 14(2): 142-147. https://doi.org/10.1016/j.nepr. 2013.06.013

[18] Robinson, L., Behi, O., Corcoran, A., Cowley, V., Cullinane, J., Martin, I., Tomkinson, D. (2015). Evaluation of whatsapp for promoting social presence in a first year undergraduate radiography problem-based learning group. Journal of Medical Imaging \& Radiation Sciences, 46(3): 280-286. https://doi.org/10.1016/j.jmir.2015.06.007

[19] Turan, S., Elcin, M., Odabas, O., Ward, K., Sayek, I. (2009). Evaluating the role of tutors in problem-based learning sessions. Procedia - Social and Behavioral Sciences, 1(1): 5-8. https://doi.org/10.1016/j.sbspro.2009.01.005

[20] Warren, S.J., Dondlinger, M.J., Mcleod, J., Bigenho, C. (2012). Opening the door: An evaluation of the efficacy of a problem-based learning game. Computers \& Education, 58(1): 397-412. https://doi.org/10.1016/j.compedu.2011.08.012

[21] Bearn, D.R., Chadwick, S.M. (2010). Problem-based learning in postgraduate dental education: a qualitative evaluation of students' experience of an orthodontic problem-based postgraduate programme. European Journal of Dental Education Official Journal of the Association for Dental Education in Europe, 14(1): 26-34. https://doi.org/10.1111/j.16000579.2009.00588.x

[22] Yeung, E., Au-Yeung, S., Chiu, T., Mok, N., Lai, P. (2003). Problem design in problembased learning: evaluating students' learning and self-directed learning practice. Innovations in Education and Teaching International, 40(3): 237-244. https://doi.org/10.1080/14703290 $\underline{32000103762}$

[23] Carlisle, C., Ibbotson, T. (2005). Introducing problem-based learning into research methods teaching: student and facilitator evaluation. Nurse Education Today, 25(7): 527-541. https://doi.org/10.1016/j.nedt.2005.05.005

[24] Alexander, J.G., Mcdaniel, G.S., Baldwin, M.S., Money, B.J. (2002). Promoting, applying, and evaluating problem-based learning in the undergraduate nursing curriculum. Nursing Education Perspectives, 23(5): 248-253.

[25] Gulash, S.Z., Atilla, C. (2012). Evaluating computer assisted problem based learning environment for endocrine system in human beings in view of professionals. Procedia Social and Behavioral Sciences, 47(1): 218-224. https://doi.org/10.1016/j.sbspro.2012.06 .641

[26] Jones, N.L., Peiffer, A.M., Lambros, A., Guthold, M., Johnson, A.D., Tytell, M., ..., Eldridge, J.C. (2010). Developing a problem-based learning (PBL) curriculum for professionalism and scientific integrity training for biomedical graduate students. Journal of medical ethics, 36(10): 614-619. https://doi.org/10.1136/jme.2009.035220

[27] Elsie, K.M., Gonzaga, M.A., Francis, B., Rebecca, N., Stephen, B. (2010). Evaluation of ultrasound training in the problem based learning radiography curriculum at makerere university, Uganda. Radiography, 16(4): 314-320. https://doi.org/10.1016/j.radi.2010.05. $\underline{003}$ 
Paper - Design and Construction of a PBL Based Evaluation Index System for Classroom Music...

[28] Chiou, C.K., Hwang, G.J., Tseng, J. (2009). An auto-scoring mechanism for evaluating problem-solving ability in a web-based learning environment. Computers \& Education, 53(2): 261-272. https://doi.org/10.1016/i.compedu.2009.02.006

[29] Kwan, T.Y. (2008). Student-teachers' evaluation on the use of different modes of problembased learning in teacher education. Asia-Pacific Journal of Teacher Education, 36(4): 323343. https://doi.org/10.1080/13598660802375933

[30] Jones, M. (2008). Developing clinically savvy nursing students: an evaluation of problembased learning in an associate degree program. Nursing Education Perspectives, 29(5): 278283.

[31] Chappell, A. (2006). Using the 'grieving' process and learning journals to evaluate students' responses to problem-based learning in an undergraduate geography curriculum. Journal of Geography in Higher Education, 30(1): 15-31. https://doi.org/10.1080/03098260500499584

[32] O'Brien, E., Mccarthy, J., Hamburg, I., Delaney, Y. (2019). Problem-based learning in the Irish SME workplace. Journal of Workplace Learning, 31(6): 391-407. https://doi.org/10. 1108/JWL-10-2018-0131

[33] Compton, R.M., Owilli, A.O., Norlin, E.E., Murdoch, N. (2020). Does problem-based learning in nursing education empower learning. Nurse Education in Practice, 44: 102752. https://doi.org/10.1016/j.nepr.2020.102752

[34] Ghasemi, A., Ashoori, A., Heavey, C. (2021). Evolutionary learning based simulation optimization for stochastic job shop scheduling problems. Applied Soft Computing, 106: 107309. https://doi.org/10.1016/j.asoc.2021.107309

[35] Liu, L., Du, X., Zhang, Z., Zhou, J. (2019). Effect of problem-based learning in pharmacology education: a meta-analysis. Studies In Educational Evaluation, 60: 43-58. https://doi.org/10.1016/j.stueduc.2018.11.004

\section{$7 \quad$ Authors}

Mengsi Huang, rewarded as Master of Arts from Wuhan Conservatory of Music. Since 2012, She work is as the person in charge of instrument tutoring in Hubei Engineering University, and her major interest is violin performance and teaching (email: lareina8811@163.com).

Yingxue Zhang, female, received Bachelor of Arts degree from Academy of Music Hubei Engineering University in 2010 and received Master of Engineering in Software Engineering from the Software College of Huazhong University of Science and Technology in 2015. Now she works in Hubei Engineering University as a lecturer. Her main research directions contain Computer Music and Multimedia Vocal Analysis.

Article submitted 2021-06-21. Resubmitted 2021-07-27. Final acceptance 2021-07-29. Final version published as submitted by the authors. 